\title{
The ASEAN Single Shipping Market: Towards a Regional Cabotage Regime
}

\section{Chinyere Ezeoke*}

\begin{abstract}
ASEAN's goal of establishing a single shipping market is consistent with its desire to create a highly integrated, connected and competitive region in which cross-border, intra-ASEAN establishment and provision of shipping services is permitted. However, the measures currently being mapped out for achieving the single shipping market have not included liberalizing cabotage. This article argues that abolishing cabotage by removing the prohibition on the ASEAN ship-owners to engage in each other's domestic shipping is a necessary requirement to fully achieve a single shipping market. It discusses the cabotage regimes in the four ASEAN States, namely Malaysia, Indonesia, the Philippines and Thailand. It highlights the vessel registration, licensing and manning requirements of each State. Further, the article discusses the regulatory provisions that exclude foreign ship-owners from domestic shipping and the scope of the exemptions from cabotage. Finally, it makes recommendations on how the disparate regulatory provisions can be harmonized through the adoption of an ASEAN agreement on cabotage.
\end{abstract}

\section{Keywords}

ASSM, AEC, Maritime Cabotage, EU Regulation, Malaysia, Indonesia, The Philippines, Thailand

* Senior Lecturer at Faculty of Law of the University of Malaya, Malaysia. LL.M (Nottingham), D.Phil (Buckingham). ORCID: http://orcid.org/0000-0003-2522-191. The author may be contacted at: cmezeoke@um.edu.my/Address: Faculty of Law, University of Malaya, 50603, Kuala Lumpur, Malaysia. 


\section{Introduction}

The ASEAN Single Shipping Market ("ASSM") is an initiative of the ASEAN Economic Community ("AEC"). ${ }^{1}$ The ASSM aims at improving the capacity, connectivity and competitiveness of the maritime sector in the region. ${ }^{2}$ The target of the AEC is to create an ASEAN single market and production base to facilitate the free flow of goods, services, capital and skilled labor. ${ }^{3}$ The AEC Blueprint 2015 envisaged that the targets should have been implemented by $2015 .{ }^{4}$ However, as this did not happen, some of the measures are now prioritized under the current AEC Blueprint 2025. ${ }^{5}$ The ASSM entails liberalizing internal frontiers within the ASEAN States to create an area in which shipping service providers have unrestricted access to establish and operate across national borders, subject to domestic regulations. ${ }^{6}$

The primary purpose of this research is to demonstrate that the liberalization of the maritime cabotage trade of the ASEAN Member States is an essential prerequisite towards achieving a Single Shipping Market in the ASEAN. The EU experience of creating a single market shows that this can only be achieved through deep regional economic integration. ${ }^{7}$ A single market in the ASEAN maritime transport will necessarily involve enacting a regulation to remove cabotage restrictions and to harmonize Member States' shipping policies. ${ }^{8}$

1 The AEC is one of the three pillars of the ASEAN, together with the ASEAN Political-Security Community ("APSC") and the ASEAN Socio-Cultural Community ("ASCC"). See ASEAN Charter pmbl. \& Annex, available at http://www. asean.org/wp-content/uploads/2012/05/11.-October-2015-The-ASEAN-Charter-18th-Reprint-Amended-updated-on05_-April-2016-IJP.pdf (last visited on Mar. 25, 2017).

2 ASEAN Economic Community Blueprint 2015 (2008) (AEC Blueprint 2015), ๆ 50, available at http://asean.org/ wp-content/uploads/archive/5187-10.pdf (last visited on Apr. 20, 2017).

3 ASEAN Charter art. 1(5).

4 AEC Blueprint 2015, ๆ 5.

5 ASEAN Economic Community Blueprint 2025 (2015) (AEC Blueprint 2025), ๆ 48(iii), available at http://www. asean.org/wp-content/uploads/images/2015/November/aec-page/AEC-Blueprint-2025-FINAL.pdf (last visited on Apr. 20, 2017). It states: "Establish an ASEAN Single Shipping Market ("ASSM") and promote maritime safety, security and strategic economic corridors within ASEAN, through the following key measures: (a) continue to strengthen maritime connectivity within ASEAN through the establishment of ASSM regional transport cooperation and effective implementation of the International Maritime Organization ("IMO") conventions towards realizing an integrated, efficient, and competitive maritime transport, including fostering a culture of maritime safety within ASEAN."

6 Maritime Institute of Malaysia, Towards a Single Shipping Market in South East Asia (July 25, 2011), available at $\mathrm{http}: / /$ www.mima.gov.my/v2/?m=posts\&c=shw_details\&id=193 (last visited on Mar. 25, 2017).

7 P. Lloyd, What is a Single Market? Application to the Case of ASEAN, in Brick By Brick: The BuILding OF AN ASEAN ECONomic Community 15 (D. Hew ed., 2007).

8 The features of the EU internal market (as stated in Article 8A of the Single European Act of 1987 O.J.L 169/1) are in similar terms with Article 1(5) of the ASEAN Charter. The latter provides for the establishment of the ASEAN as a single market and production base. 
This paper is composed of six parts including a short Introduction and Conclusion. Part two will provide an overview of the ASSM initiative and its implementation under the ASEAN maritime transport action plans and roadmaps. Part three will discuss the rationale behind the adoption of cabotage policy in the ASEAN countries. It evaluates the merits of abolishing cabotage restrictions in intra-ASEAN shipping trade. Part four will describe the cabotage regime in four ASEAN Member States with significant domestic shipping such as Malaysia, Indonesia, Thailand and the Philippines. It identifies the major disparities in these countries with respect to the registration, licensing and manning of ships. It also discusses the prohibitions and exemptions that apply to foreign vessels, the penalties for non-compliance and the geographical limits in which cabotage is enforced. Part five will proffer some policy and regulatory recommendations that the ASEAN could consider to harmonize its rules and liberalize cabotage.

\section{The ASEAN Single Shipping Market}

Maritime transport facilitates international trade, and is therefore key to the economic development of the ASEAN States. In terms of traffic volume, it is the most important mode of transport the ASEAN's numerous islands are mainly connected by maritime transport. In the Master Plan on Connectivity, ${ }^{9}$ the ASEAN leaders committed to the formation of a single shipping market which would lead to a stronger ASEAN maritime sector operating efficiently by delivering goods at competitive prices. The Maritime Transport Working Group ("MTWG") describes the ASSM as the region within the ASEAN Member States where the free flow of shipping services can be secured. ${ }^{10}$ The point is also reiterated in the Roadmap towards an Integrated and Competitive Maritime ASEAN (hereinafter the Roadmap). ${ }^{11}$ Identifying specific ASSM measures, the Roadmap stresses the elimination of discriminatory measures in corporate establishments across the ASEAN as one of the main objectives.

The achievement of the ASSM is also a target under the current transport action

9 See Master Plan on ASEAN Connectivity 2025, available at http://asean.org/storage/2016/09/Master-Plan-onASEAN-Connectivity-20251.pdf (last visited on Apr. 20, 2017).

10 The MTWG developed the ASSM Implementation Framework working closely with the Malaysia Expert Group. See supra note 6.

11 See Report on 21st ASEAN MTWG Meeting on Roadmap towards an Integrated and Competitive Maritime Transport in ASEAN (2011), ๆ 5, available at http://www.asean.org/uploads/archive/21152.pdf (last visited Apr. 24, 2017). 
plan: the ASEAN Transport Strategic Plan 2016-2025. ${ }^{12}$ The plan is for an in-depth study of the costs and benefits of the ASSM, followed by its full operationalization, to be completed by 2019. The implementation of these plans would mean that existing barriers that prevent the ASEAN ship-owners from engaging and carrying out operations in other countries in the region would be removed. Furthermore, the AEC Blueprint 2015 goals for the removal of restrictions in Mode 1 and Mode $3^{13}$ of services supply would imply that the barriers in cross-border shipping services and the permanent establishment of ship-owners in other ASEAN States should be eliminated. ${ }^{14}$ Currently, the ASEAN and non-ASEAN actors are treated alike in domestic shipping, but this is at variance with the tenets of a regional single market $^{15}$ and should be discontinued. Instead, regional economic integration should mean that ASEAN Member States are treated more preferentially than non-ASEAN members in the provision of shipping services. ${ }^{16}$

\section{Abolishing Cabotage Restrictions in the ASEAN}

Maritime cabotage refers to the coastal and domestic shipping trade of a country. ${ }^{17}$ It involves the transport of cargo and passengers from one port or place in a country to another port or place in the same country. ${ }^{18}$ Typical cabotage regulations reserve a country's cabotage trade to its nationals and vessels flagged in the country to the

12 See Kuala Lumpur Transport Strategic Action Plan (ASEAN Transport Strategic Plan) 2016-2025, (2015), ๆ 43, available at $\mathrm{http}: / /$ www.asean.org/storage/2016/01/11/publication/KUALA_LUMPUR_TRANSPORT_STRATEGIC_ PLAN.pdf (last visited Apr. 24, 2017).

13 Mode 1 of Supply of Services refers to Cross-Border Supply where the services move across the national border of an ASEAN country. Mode 3 is the Commercial Presence where the producer moves across the border to provide services through commercial establishment in an ASEAN country other than its own. See ASEAN Integration in Services 44 (2015), available at http://www.asean.org/wp-content/uploads/2015/12/ASEAN-Integration-in-Services-(Dec\%20 2015).pdf (last visited Apr. 24, 2017).

14 AEC Blueprint 2015, ๆ 21(v). It requires the facilitation of free flow of services by specific actions which include: removing substantially all restrictions on trade in service for all service sectors; schedule packages of commitments to achieve no restriction to Modes 1 and 2 (except for bona fide regulatory reasons agreed by all); allow up to 70 percent foreign equity participation by 2015 and progressively remove other Mode 3 market access limitations by 2015 .

15 Lloyd, supra note 7, at 33.

16 Lay Hong Tan, Law and Policy in ASEAN Economic Integration, 28 Asia Bus. L. Rev. 3 (2002).

17 Black's Law Dictionary 243 (10th ed. 2014).

18 B. Parameswaran, The Liberalisation of Maritime Transport Services: With Special Reference to the WTO/ GATS FramewORK 166 (2004). 
exclusion of foreigners. ${ }^{19}$ Cabotage restrictions are quite common, ${ }^{20}$ but differ in severity between countries. ${ }^{21}$ Sometimes, however, countries enter into bilateral ${ }^{22}$ or multilateral (regional) agreements ${ }^{23}$ to open up their domestic shipping to shipowners from other States.

Many ASEAN States actively promote private investment in the shipping industry. For many reasons, however, they maintain a cabotage policy which reserves domestic and coastal shipping to nationals. Some of the reasons include national security, creation of jobs and the protection of the shipping industry from competition. The ASEAN States want a strong domestic fleet to ensure regular and affordable services for all communities. In many cases, intra-regional and domestic operations, particularly those between remote islands and ports, are unavailable or prone to inefficiency. ${ }^{24}$ Naturally, they are keen to avoid relying on foreign shipowners to service these routes as they are not considered committed, consistent or affordable. The exclusion of foreigners from the lucrative routes allows local shipowners to achieve sustainable growth and dominance in domestic shipping. The more vessels registered under the national flag, the more internally generated revenue will be collected for the country. ${ }^{25}$

Despite the above justifications, cabotage restriction in the ASEAN has disadvantages. ${ }^{26}$ With respect to the major (and more lucrative) trading routes,

19 W. Oyedemi, Cabotage Regulations and the Challenges of Outer Continental Shelf Development in the United States 34 Hous. J. Int'L L. 607 (2012). See also R. Petrova, Cabotage and the European Community Common Maritime Policy: Moving towards Free Provision of Services in Maritime Transport, 21 FordHAm Int'L L. J. 1039 (1998). Here, cabotage refers to "the right to engage in trade and navigation in coastal waters and to the restriction of that right to domestic carriers."

20 M. Brooks, Maritime Cabotage: International Market Issues in the Liberalisation of Domestic Shipping, in THE Regulation of International Shipping: International and Comparative Perspectives 293 (A. Chircop ed., 2012).

21 The US has a very strict cabotage law. See The U.S. Merchant Marine Act 1920 (The Jones Act), 46 U.S. Code $\$ 55102$ (2006). It reserves domestic shipping to vessels built and flagged in the US as well as owned and manned by American citizens. Cabotage is also enforced in New Zealand (Section 198 of Marine Transport Act 1994); in Canada (Section 3 of Coasting Trade Act 1992); in Nigeria (Section 3 of the Coastal and Inland Shipping (Cabotage) Act 2003).

22 E.g., the Cross-Straits Sea Transport Agreement 2008 abolishes cabotage in the Taiwan Straits between mainland China and Taiwan. See Rong-Her Chiu, The Effect of Cabotage on the Cross-Strait Sea Transport Agreement between China and Taiwan, 44 J.M.L.C. 69 (2013).

23 See, e.g., the EU cabotage regulations, Council Regulation (EEC) No 3577/92 of 7 December 1992 Applying the Principle of Freedom to Provide Services to Maritime Transport within Member States (maritime cabotage) O.J.L. 364, 12/12/1992. The regulation abolished cabotage between the EU Member States. See Petrova, supra note 19.

24 PDP Australia Pty Ltd and Meyrick and Associates, Promoting Efficient and Competitive Intra-ASEAN Shipping Services, REPSF Project No. 04/001 (2005), available at http://www.asean.org/storage/images/archive/AADCPREPSF-Project/Main-Report.pdf (last visited on Mar. 25, 2017).

25 J. Batongbacal, Cabotage, 3 Ocean L. \& Pol'y Series 170 (1999).

26 J. Tongzon, The Challenge of Globalisation for the Logistic Industry: Evidence from Indonesia, 51 TranSAP. J. 5 (2010). 
the ASEAN ship-owners will only benefit if big foreign shipping companies are excluded from the ASEAN waters. However, on the remote, underserviced routes (where non-ASEAN multinationals are unlikely to be found), most ASEAN shipowners will not have a competitive advantage over the local operator as both are comparatively resourced. ${ }^{27}$ In those cases, placing a barrier against other ASEAN Members is counterproductive for the following reasons. First, the removal of cabotage restriction for the ASEAN ship-owners would improve connectivity and competitiveness in the remote and underserviced routes. ${ }^{28}$ Second, most ASEAN States do not permit foreign ships to call at more than one domestic port on a voyage. ${ }^{29}$ Due to the restriction on foreign ships from engaging in feedering ${ }^{30}$ (and the practice of not consolidating cargo) in the cabotage trade, economies of scale cannot be easily achieved by large vessels. ${ }^{31}$ Consequently, cabotage restrictions lead to an increase in operating costs. In the less developed and remote regions of the

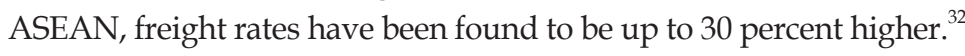

In the early days of the ASEAN, the economies of the Members States were less diversified. The countries were at the same level of development and offered similar tradeable goods and services. As they competed rather than complemented each other at that time, ${ }^{33}$ some earlier economic cooperation programs failed. ${ }^{34}$ This has changed quite a lot. With the entrance of formerly non-market economies ${ }^{35}$ into the ASEAN, sector specializations and complementation in the regional market have been created in which sustainable economic benefit can be derived by both rich and poor alike. ${ }^{36}$

27 East ASEAN Growth Area (BIMP-EAGA) including the Brunei, Indonesia, Malaysia and the Philippines set up a sub-regional economic cooperation for the purpose of enhancing the maritime connectivity of the remote parts of these countries. The initiatives aim to make maritime transport services more efficient and competitive. See the official website of BIMP-EAGA, available at https://bimpeagabc.com (last visited on Mar. 25, 2017).

28 F. Zen \& M. Anandhika, ASEAN Maritime Connectivity: Overview and Insights, Paper presented in ERIA conference on Logistics and Maritime Studies on One Belt One Road, May 10, 2016, available at http://app.lms.polyu.edu.hk/ OBOR2016/files/slides/(PS-A)\%20Zen,\%20Fauziah.pdf (last visited on Mar. 25, 2017).

29 J. Tongzon \& S. Lee, The Challenges of Economic Integration: the Case of Shipping in ASEAN Countries, 28 PAC. REVIEWER 497 (2015).

30 In feedering service, empty or loaded containers from different ports in a region are carried to a central container terminal or hub where they are loaded into bigger vessels for long-haul ocean voyage.

31 Tongzon \& Lee, supra note 29.

32 P. Dee, Services Liberalisation: Towards the ASEAN Economic Community, in DeEPening EAst Asian Economic InTEGRATION: ERIA Research Project Report No. 28, 49 (J. Corbett \& S. Umezaki eds., 2009).

33 Tan, supra note 16 , at 4.

34 E.g., the ASEAN Industrial Projects Scheme 1976 and the Preferential Trading Arrangements 1977.

35 Namely, Cambodia, Vietnam, Myanmar and Laos.

36 Tan, supra note 16. 
If a cabotage region is established in the ASEAN, at the initial stages the poorer countries like Myanmar, Vietnam, Cambodia and Laos may lack the capital to invest in other countries' shipping industry. However, they could benefit immediately from the more modern fleets of the richer countries servicing every part of their countries. ${ }^{37}$ Indonesia and the Philippines, being archipelagic, ${ }^{38}$ will benefit from more ASEAN vessels calling at their numerous remote ports and islands. ${ }^{39}$ This is certainly preferable to non-ASEAN vessels from industrialized countries that could provide these services at higher cost.

The exclusion of non-ASEAN multinationals that currently dominate the ASEAN's offshore oil and gas shipping industry will certainly create more opportunities for the ASEAN ship-owners. ${ }^{40}$ They would invest in more capital intensive and specialized vessels needed in that industry. Also, unemployed seafarers from the Philippines, Vietnam and Myanmar could benefit from more shipping jobs being created across the ASEAN. This would be especially so in Malaysia and Singapore which are experiencing a shortage of maritime labor. ${ }^{41}$ Furthermore, the hub ports in the ASEAN would also experience decongestion if cabotage is abolished. Cargo which otherwise would have been transshipped to domestic ships at these major ports could be carried in the ASEAN ships to their final destination. $^{42}$

The Roadmap highlights the desire of the ASEAN Members to retain some restrictions in domestic shipping in order to "maintain certain levels of maritime capability for security reasons." ${ }^{43}$ However, the Roadmap and the various Strategic Transport Action Plans contain measures for improving maritime security. ${ }^{44}$

37 J. Tongzon \& S. Lee, Achieving and ASEAN Single Shipping Market: Shipping and Logistic Firms' Perspective, Mar. PoL'y \& MGMT. 11 (2015).

38 An archipelago is defined as "a group of islands, including parts of islands, interconnecting waters and other natural features which are so closely interrelated that such islands, waters and other natural features form an intrinsic geographical, economic and political entity, or which historically have been regarded as such." See The United Nations Convention on the Law of the Sea of 1982 ("UNCLOS"), 1833 U.N.T.S. 3; 21 I.L.M. 1261, art. 46(b). Indonesia is the world's largest archipelagic state consisting of over 17,500 islands, followed by the Philippines with about 7,600 islands.

39 S. Pushpanathan, ASEAN Connectivity and the ASEAN Economic Community (2010), available at http://asean. org/?static_post=asean-connectivity-and-the-asean-economic-community-by-s-pushpanathan-deputy-secretarygeneral-of-asean-for-asean-economic-community-2 (last visited Mar. 25, 2017).

40 Especially those from the richer countries, namely Singapore, Malaysia, Brunei, Indonesia and the Philippines.

41 Supra note 24, ch. VI.D.

42 Zen \& Anandhika, supra note 28.

43 See Report on 21st ASEAN MTWG Meeting on Roadmap towards an Integrated and Competitive Maritime Transport in ASEAN (2011), ๆ 2, available at http://www.asean.org/uploads/archive/21152.pdf (last visited Apr. 24, 2017).

44 See Final Report on ASEAN Strategic Transport Plan 2011-2015 (2010), ๆ 4.6.3, available at http://www.asean.org/ 
Considering that the security concerns are being collectively addressed at the ASEAN regional level and have seen significant improvements due to measures taken in recent times, ${ }^{45}$ delaying the abolition of cabotage restrictions for that reason alone does not seem justified for the ASEAN. In any case, piracy, armed robbery and terrorism at sea are common to most ASEAN countries with coastal shipping. ${ }^{46}$ It is therefore difficult to see how the opening up of intra-ASEAN domestic shipping would worsen security for individual countries.

Current concerns of the ASEAN States about cabotage liberalization equally bothered the EU States when the EU introduced EU Regulation 3577/92 ${ }^{47}$ to liberalize maritime transport services. ${ }^{48}$ Owing to those concerns, maritime transport service in Europe was one of the last service sectors to be liberalized. In fact, the EU Regulation 3577/92 only came to be enacted after the EU Parliament took action against the Council of the European Communities for failing to take action to adopt a common transport policy. ${ }^{49}$ The legislation then enabled the EU ship-owners to participate in each other's domestic shipping. Similar action should be taken in the ASEAN.

\section{Cabotage Regulations in the ASEAN Countries}

The regulatory frameworks for cabotage in the ASEAN countries vary in their restrictions on coastal and domestic shipping. The aspects discussed below concern the requirements for ship-owners to operate in the coastal and domestic shipping markets of Malaysia, Indonesia, Thailand and the Philippines.

storage/images/archive/AADCP-REPSF-Project/Main-Report.pdf (last visited on Mar. 25, 2017); Kuala Lumpur Transport Strategic Action Plan, supra note 12.

45 Id. $ๆ$ 3.4.4.

46 The problem is dealt with collectively under the Regional Agreement on Combating Piracy and Armed Robbery against Ships in Asia ("ReCAAP") 2004 which has been signed by 20 countries including some of the ASEAN Member States. The Agreement is an intergovernmental initiative to combat maritime crimes. See the official website of ReCAAP, available at http://www.recaap.org (last visited on Mar. 25, 2017).

47 Council Regulation (EEC) No 3577/92 of 7 December 1992 Applying the Principle of Freedom to Provide Services to Maritime Transport within Member States (maritime cabotage) O.J.L. 364, 12/12/1992 (EU Regulation 3577/92).

48 A. Bredima-Savopoulou \& J. Tzoannos, The Common Shiping Policy of the EC 41 (1990).

49 Case 13/83, European Parliament v. Council of the European Communities, 1985 E.C.R. 1513, available at http://eurlex.europa.eu/legal-content/EN/TXT/?uri=CELEX\%3A61987CJ0302 (last visited on Apr. 25, 2017). 


\section{A. Vessel Registration}

Malaysia, Indonesia, Thailand and the Philippines maintain closed registries for the domestic shipping trade. ${ }^{50}$ Unlike open registries, closed registries link the eligibility to register a vessel to the nationality of the ship owner. In closed registries, only vessels owned by nationals can fly the national flag. ${ }^{51}$

\section{Malaysia}

Malaysia maintains two vessel registries. The ordinary registry admits vessels owned by citizens or companies with majority Malaysian ownership, while the international registry is open to vessels owned by foreign companies established in Malaysia. Under the Malaysian Merchant Shipping Ordinance 1952 ("MSO"), ownership of a 'Malaysian ship' is the general registrability criterion. For the ordinary registry, the ship must be owned by a Malaysian citizen or a company incorporated in Malaysia. ${ }^{52}$ The company must have its principal office in Malaysia and its management carried out in Malaysia. The majority of both shareholders and directors in the company must be Malaysian citizens who must hold their shares free of any trust in favor of foreigners. $^{53}$

The Malaysian international registry was created in 2006. Pursuant to Section 66B(1) of the MSO, ships owned by a company incorporated in and having an office in Malaysia but with majority foreign shareholders can be registered. The company's paid-up capital must not be less than 10 percent of the value of the first ship registered or 1 million Ringgit, whichever is higher. ${ }^{54}$ The ship manager must be a resident or a company incorporated in Malaysia with the principal place of business in Malaysia. ${ }^{55}$ Registrable ships are required to be mechanically propelled, be not less than 1,600 gross tons and under 15 years old if a tanker, or 20 years old for other kinds of vessels. ${ }^{56}$

\section{Indonesia}

Under Article 158 of Indonesia's Maritime Law No. 17/2008, a ship is registrable if it

50 Cambodia, Vietnam and Singapore operate open registries.

51 E. Powell, Taming the Beast: How International Legal Regime Creates and Contains Flags of Convenience, 19 AnNuAL J. InT'L \& Comp. L. 272 (2013).

52 MSO, § 11(1).

53 Id.

54 Id. $\S 66 \mathrm{D}$.

55 Id. $\S 66 \mathrm{C}$.

$56 \quad I d . \S 66 \mathrm{E}$. 
is at least 7 gross tons in weight. It must be owned by an Indonesian citizen or legal entity established in and domiciled in Indonesia or by a joint venture incorporated in Indonesia where the majority of shares (i.e. 51 percent) are owned by Indonesian citizens. ${ }^{57}$ Seagoing vessels listed in the Indonesian registry are issued a Certificate of Nationality as proof of the vessel's nationality. ${ }^{58}$

\section{Thailand}

Registration of a vessel for trading in Thai waters is governed by the Thai Vessels Act $1938 .^{59}$ By virtue of Section 7, the owner of the vessel must be a Thai national, a partnership or a company. In the case of a partnership, a minimum of 70 percent of the partners must be Thai nationals. For a corporation, not less than 50 percent of the directors must be nationals and not less than 70 percent of the company's registered or paid-up share capital must be owned by Thai nationals. Thai nationals are prohibited from acting as nominee shareholders for foreigners. ${ }^{60}$

Different conditions apply if the vessel is to be used for international transport. Under Section 7 bis of the Act, the company which owns the vessel must be established under Thai law and have a minimum of 51 percent Thai directors. Also, a minimum of 51 percent of the shares must be held by Thai citizens. This reduced shareholding requirement aims to encourage more foreign equity participation in large ocean-going vessels used in international shipping trade. Vessels up to 10 gross tons in weight are registrable. ${ }^{61}$

\section{The Philippines}

Article IV(1) of the Philippines' Maritime Industry Authority ("MARINA") Circular No. 2013-02 ${ }^{62}$ requires all ships in domestic ownership to be duly registered and issued with a Certificate of Philippine Registry ("CPR") and Certificate of Ownership. Domestic ownership means the ownership vested in citizens of the Philippines or corporations, cooperatives or associations organized under the laws of the Philippines, at least 60 percent of the capital stock or capital of which is wholly owned by citizens of the Philippines. ${ }^{63}$ The company registering a ship must have

57 Indonesian Maritime Law No. 17/2008, art. 158(2)(b) \& (c).

58 Indonesian Minister of Transportation Regulation No. 13/2012, art. 57.

59 Thai Vessels Act (No. 6) 1997.

601991 Thai Vessels Act (No. 5), §7 ter.

$61 \quad 1938$ Thai Vessels Act, $\S 8$.

62 It was made pursuant to the Domestic Shipping Development Act ("DSDA") 2004.

63 DSDA 2004, § 3(c) \& MARINA Circular No. 2013-02, art. III(3). 
its principal office or branch in the Philippines. ${ }^{64}$ Ships of any size are registrable provided that they are class-maintained. ${ }^{65}$

Foreign ships bareboat chartered by a Philippine national for not less than one year can be registered under the Philippines Registry. ${ }^{66}$ A Philippine national is defined using similar criteria as that of domestic ship-ownership. ${ }^{67}$ If the charterer is a non-ship owning company, it can register a maximum of 10 bareboat chartered ships, but no limit applies to charterers who are ship owning companies. ${ }^{68}$ The shipping company must have up to 7 million Pesos in paid-up share capital. ${ }^{69}$ Its principal officers must be Filipinos residing in the Philippines who have up to five years' shipping industry experience. All crew on board the chartered vessel must be Filipinos and be Standards of Training, Certification and Watchkeeping for Seafarers 1978 ("STCW") certified..$^{70}$ Also, a 4.5 percent withholding tax is payable and the company must deposit 100,000 Pesos in favor of MARINA with a local bank to cover any default in taxes and penalties. ${ }^{71} \mathrm{~A}$ CPR issued to a bareboat charterer is valid until the end of the charter period. ${ }^{72}$

\section{B. Vessel Operation License}

The Domestic Shipping Licensing Board ("DSLB") of Malaysia issues licenses to Malaysian flagged vessels to engage in domestic shipping. It is a criminal offence to carry out domestic shipping without a license. ${ }^{73}$ Licenses are issued per ship unconditionally, conditionally or temporarily. ${ }^{74}$ An unconditional license is valid for two years if the vessel is less than 10 years old. The company must have at least 30 percent bumiputra ${ }^{75}$ participation in terms of shareholding equity. The directors,

64 MARINA Circular No. 2013-02, art. VII(A)(1).

65 Revised Rules and Regulations Implementing Republic Act No. 9295 (2009) (Revised Implementing Rules 2009), Rule III, $\S 6.4$.

66 MARINA Memorandum Circular No. 182 (2003), art. V(2).

67 Id. art. III (6).

$68 I d$. art. IV(4).

69 Id. art. $\mathrm{V}(1)(1.2)$.

70 Id. art. $\mathrm{V}(6)$ \& (8). The International Convention on Standards of Training, Certification and Watchkeeping for Seafarers 1978 sets the qualification criteria for masters, officers and watch personnel on board seagoing merchant ships. All the ASEAN states considered in this article have ratified the convention.

71 MARINA Memorandum Circular No. 182 (2003), art. V(13).

72 Id. art. VIII (2).

73 MSO, § 65A.

74 Ministry of Transport Malaysia, Information on the Application for Domestic Shipping Licence, available at http:// edsl.mot.gov.my/public/public.cfm?itype=details (last visited on Mar. 25, 2017).

75 The term refers to the Malay race and the indigenous peoples of Malaysia. 
employees and crew must consist of at least 75 percent Malaysian citizens. ${ }^{76}$ If these requirements are not met, or the vessel is between 10 and 19 years old, an unconditional license may be issued for one year. ${ }^{77}$ A conditional license may be issued when a company does not meet some of the foregoing requirements. Temporary licenses for not more than three months are issued to foreign flagged vessels engaged temporarily in Malaysia. ${ }^{78}$

In Indonesia, Article 28 of Maritime Law No. 17/2008 requires shipping companies to obtain a Sea Transport Business Permit to carry out sea transport business. The applicant company is required to possess a ship of at least 175 gross tons which is flagged in Indonesia. In the case of a joint venture with foreigners, the company must possess at least one Indonesian flagged vessel that is not less than 5000 gross tons and manned by Indonesian citizens. ${ }^{79}$

Section 137 of the Navigation in Thai Waters Act $1913^{80}$ provides for licensing a vessel by application to the harbor master and payment of applicable fees. The same documents required for registering the vessel are needed to apply for a license. ${ }^{81}$

The Philippines-flagged vessels in domestic shipping must acquire a license referred to as the Certificate of Public Convenience ("CPC") from MARINA. ${ }^{82}$ The application for CPC must state the proposed service, the ship(s) to be used, the route, area, ports of origin and destination to be served. The applicant must be preaccredited by MARINA and be financially capable of sustaining the ship's operation and meeting any third party claims. There must be proof of the beneficial effect of the proposed service for the route to be served. ${ }^{83}$ The CPC is valid for a maximum of 25 years. ${ }^{84}$ One is issued per ship owner to cover all the operated vessels. The licensee must ensure regular service on the authorized route. Suspension of service by a licensee for over three months without authorization can result in imposition of a fine, penalties or cancellation of the license. ${ }^{85}$

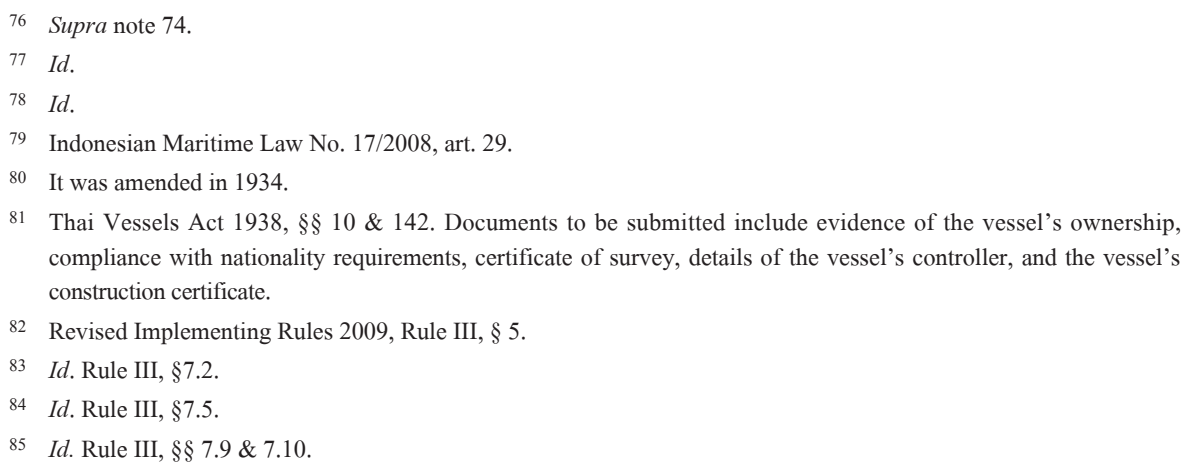




\section{Manning}

Malaysia's DSLB provisions require the crew on board flagged vessels to comprise at least 75 percent Malaysian citizens in order for the vessel to be licensed to participate in the domestic shipping. ${ }^{86}$ Also, at least 30 percent of the shipping company's employees must be bumiputra Malaysians in order to obtain the two year unconditional license. ${ }^{87}$

Article 136 of the Indonesian Maritime Law No. 17/2008 requires that Indonesian flagged vessels be manned by Indonesian citizens. Exemptions may be granted if provided by a regulation.

Section 50 of the Thai Vessels Act 1938 stipulates that every crew of a vessel registered for trading in Thai waters shall be a Thai national. ${ }^{88}$ For vessels registered under Section 7 bis for international transport, the crew may comprise only 51 percent nationals. All ships flying the Philippines flag are required to be manned by an all-Filipino crew. ${ }^{89}$

\section{Prohibition of Foreigners from Domestic Shipping}

By virtue of Section 11 of the Merchant Shipping Ordinance 1952, only owners of a Malaysian ship qualified to be entered in the ordinary registry (as opposed to the international registry) can engage in domestic shipping. Only Malaysian citizens or a Malaysian company with Malaysian majority shareholders can own ships for the ordinary registry. ${ }^{90}$ Foreign ships are excluded from the ordinary registry.

Article 8(1) of Indonesia's Maritime Law No. 17/2008 prohibits foreign vessels (not owned by a citizen or an Indonesian majority owned company) from operating in Indonesian waters. Prior to the 2008 revision of the cabotage policy, Indonesian ship-owners faced stiff competition from foreign vessels in the domestic market. ${ }^{91}$

Section 47 of the Thai Vessels Act 1938 excludes foreigners from domestic shipping. It provides that only Thai vessels registered under the provision of Section 7 of the Act may engage in trading in Thai waters. Foreigners not qualified to own and register a Thai vessel cannot circumvent this provision by leasing and engaging

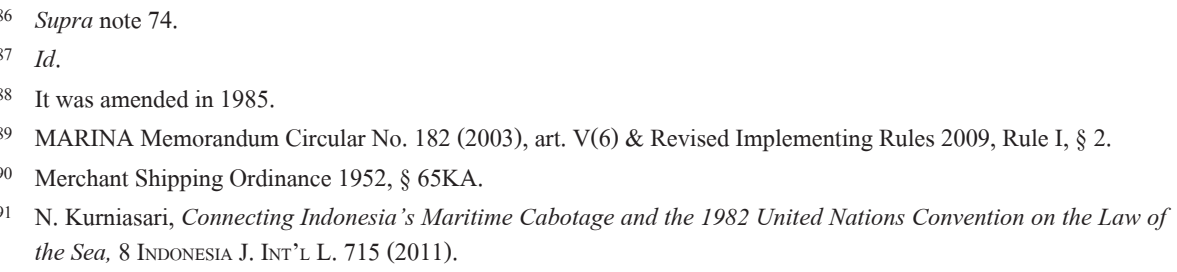


a Thai flagged vessel in domestic business. ${ }^{92}$

A license to engage in domestic shipping (CPC) in the Philippines can only be granted to a Philippine flag vessel operated by a domestic ship owner. Unless exempted, foreign vessels are excluded from the transport of passengers and cargo between ports and places in the Philippines. ${ }^{93}$

\section{E. Exemptions from Restrictions}

Malaysia lifted the cabotage restriction on certain major routes connected to Port Klang in line with the government's move to develop the port as a regional hub. ${ }^{94}$ Foreign ships are now allowed to carry containerized cargo between Port Klang and the ports of Penang, Tanjun Pelepas and Pasir Gudang. ${ }^{95}$ In 2009, the carriage of containerized transshipment cargo by foreign vessels was allowed between some ports in West and East Malaysia and for some passenger cruise ships. ${ }^{96}$ The shortage of specialized supply vessels needed in offshore shipping led to a further exemption from cabotage restrictions. ${ }^{97}$ Generally, foreign ships can obtain a temporary license for up to three months upon proof that no domestic ship is available for the required service. $^{98}$

Article 2 of Indonesia's Minister of Transportation Regulation No. 48/2011 stipulates that foreign ships can perform domestic shipping activities other than passenger and goods transport if an Indonesian-flagged vessel is not available. Also, foreign vessels used in performing any of the five specified offshore activities ${ }^{99}$ are exempt from cabotage restriction upon receipt of a dispensation permit from the Minister of Transport. ${ }^{100}$ The exemptions are subject to various time limits, some of which have expired. ${ }^{101}$ The exemption permits are usually given for three months, up

\footnotetext{
92 Thai Vessels Act 1938, §§ 7 ter \& 7 quarter (amended in 1991).

93 Revised Implementing Rules 2009, Rule III, § 6.1.

94 F. Farid, The Malaysian Cabotage Policy, 14:2 Mar. Inst. Malaysia Bull. 10 (2007).

95 Port Klang Authority, Driving Change: PKA Re-engineers itself to take Port Klang to the Next Level GATEWAY (2009), available at http://www.pka.gov.my/phocadownload/gateway0410.pdf (last visited on Mar. 25, 2017).

96 Sabah Ports Authority, Cabotage Restrictions Had Been Relaxed Effective (June 2009), available at http://www.lpps. sabah.gov.my/?q=content/cabotage-restrictions-had-been-relaxed-effective-june-2009 (last visited on Mar. 25, 2017).

97 C. Metcalf \& J. David, The Malaysian Cabotage Policy, CLYDE \& Co., Apr. 27, 2015, available at http://www. clydeco.com/insight/article/the-malaysian-cabotage-policy (last visited on Mar. 25, 2017).

98 Supra note 74.

99 These include oil and gas survey, drilling works, offshore construction work, offshore support operations, dredging works, salvage and underwater activities.

100 Indonesian Minister of Transportation Regulation No. 48/2011, art. 10(1).

101 Id. No. 100/2016.
} 
to a maximum of one year. ${ }^{102}$

Exemption from cabotage restriction in Thailand is granted to foreign vessels if there are not enough Thai flagged vessels operating in Thai waters according to the demand of the country. ${ }^{103}$ The Minister of Transport grants permission to foreign vessels on a case-by-case basis. The permits are valid for no more than one year and subject to whatever conditions are imposed by the Minister. ${ }^{104}$

Like in other countries, the Philippines' exemption is also essentially imposed to enable large and expensive foreign vessels not locally available to work in the offshore oil, gas and infrastructure development projects. MARINA grants a Special Permit subject to proof of the proposed service's benefit and verification that no domestic vessel can undertake the work. ${ }^{105}$ The permit is valid for six months per issuance, but may be renewed for up to one or two years. ${ }^{106}$ If the permit is for a tanker, it must be double-hulled and less than 15 years old. ${ }^{107}$

The Philippines also passed the Foreign Ship Co-Loading Act in $2015 .^{108}$ The statute allows foreign vessels arriving from or departing to a foreign port to proceed beyond their original entry or departure port in the Philippines to the cargo's final port in the Philippines. ${ }^{109}$ This relaxation of cabotage was necessary to reduce high shipping costs which resulted from foreign vessels always having to transship such cargo at the first port. ${ }^{110}$ It also freed up traffic at the major ports in the country. ${ }^{111}$

\section{F. Geographical Limit of Cabotage}

Malaysia defines a "coasting trade voyage" as one in which a ship does not proceed more than thirty miles from the coast of the federation. ${ }^{112}$ This is greater than the territorial waters and contiguous zone limits within the definition of the United

102 Id. No. 48/2011, art. 10(3).

103 Thai Vessels Act 1938, art. 47 bis. (Amended by the National Executive Council Announcement (No. 162) on June 5, 1972).

104 Id.

105 MARINA Circular 2011-04, art. IV(1).

106 Id. arts. IV(6) \& V(3).

107 Id. art. $\mathrm{V}(1) \&(2)$.

108 Republic Act No. 10668.

109 Foreign Ship Co-Loading Act 2015, §4.

${ }^{110} I d$. $\S 1(\mathrm{~b})$. It state the policy behind the Act to be, among others, "to lower the cost of shipping export cargoes from the Philippine ports to international ports and import cargoes from international ports for the benefit of the consumers."

111 G. Yee \& N. Din, Twin Measures: The Philippines Competition Act and Amendment to the Cabotage Law, CLYDE \& Co., Oct. 1, 2015, available at http://www.clydeco.com/insight/article/twin-measures-the-philippines-competition-actand-amendments-to-the-cabotag (last visited on Mar. 25, 2017).

112 Merchant Shipping Ordinance 1952, §2. 
Nations Convention on the Law of the Sea 1982 ("UNCLOS"). ${ }^{113}$ Its enforcement of cabotage jurisdiction, however, goes well beyond these. This is because 'domestic shipping' as defined in Section 65A of the MSO includes services from any port or place in Malaysia to any place in the exclusive economic zone ("EEZ"). ${ }^{114}$ Such a wider breadth of cabotage jurisdiction enables Malaysia to extend enforcement to the offshore oil and gas fields which lie beyond its territorial waters.

Under Article 8(2) of Indonesia's Maritime Law No. 17/2008, foreign vessels are excluded from transport of goods and persons between islands and ports within Indonesian waters. Indonesian waters mean the territorial seas with the archipelagic waters and inland waters.

Section 3 of the Navigation in Thai Waters Act $1913^{115}$ stipulates that foreign vessels and non-Thai nationals may not operate in Thai waters. Thai waters are any territorial waters within the sovereignty of the Thai kingdom and the contiguous zone $^{116}$ of Thailand.

The Revised Implementing Rules 2009 to the Philippines Domestic Shipping Development Act 2004 defines 'domestic shipping' as shipping between the ports, territorial or internal waters of the Philippines. ${ }^{117}$ For foreign vessels granted a temporary Special Permit to operate in domestic trade, Article III(7) of MARINA Circular 2011-04 designates the reach of their operational zone as the territorial waters and the EEZ of the Philippines. However, the scope of area to which the cabotage restriction applies appears wider under the Foreign Ship Co-Loading Act 2015. This is because 'domestic cargo' is defined as including cargo carried between two Philippine ports even if in the carriage there is a call to an intervening foreign port. ${ }^{118}$ Thus, the fact that a foreign vessel called at a foreign port may not prevent the shipment from being treated as violating the cabotage restriction if all other conditions are present.

\section{G. Penalties}

According to Malaysia's MSO, a person who contravenes the prohibition against

\footnotetext{
113 UNCLOS art. 3. Territorial waters is defined as the belt of coastal water not exceeding $12 \mathrm{~nm}$ from baseline.

114 UNCLOS art. 57. The limit of the EEZ is defined as $200 \mathrm{~nm}$ from the baselines from which the breadth of the territorial sea is measured.

115 It was amended in 1997.

116 UNCLOS art. 33 (2). The limits of the contiguous zone is defined as not exceeding $24 \mathrm{~nm}$ from the baseline from which the breadth of territorial sea is measured.

117 Revised Implementing Rules 2009, § 3.

118 Foreign Ship Co-Loading Act 2015, § 2(c).
} 
non-Malaysian ships in domestic trade or fails to obtain a license or comply with any vessel registration or licensing conditions is guilty of an offence punishable with up to one year's imprisonment or a fine not exceeding 1,000 Ringgit. ${ }^{119}$

Breach of the cabotage restriction contrary to the provisions of Indonesia's Maritime Law No. 17/2008 carries a penalty of up to a 6 million Rupee fine and imprisonment for a maximum of five years. ${ }^{120}$ Thailand considers the violation of the cabotage provisions a serious criminal offence. Fines of up to 500,000 Baht or 10 years in prison can be imposed. ${ }^{121}$

In the Philippines, penalties are imposed for violating the provisions relating to vessel registration and licensing and the prohibition against foreign ships. ${ }^{122}$ Fines varying from 1 million Pesos to 5 million Pesos per ship can be imposed for not having a permit, using an expired permit or for the violation of a post-approval condition. ${ }^{123}$ Ship-owners holding a CPC may be fined for discriminating against passengers and shippers and for refusing to carry passengers or cargo without just cause. $^{124}$

\section{H. Analysis of the Cabotage Regulations}

It is clear from the provisions of the ASEAN regulations discussed above that significant discrepancies exist in the cabotage policies of the ASEAN States. Malaysia and Thailand have two registry systems, ${ }^{125}$ while the Philippines only allows the registration of foreign bareboat chartered vessels. ${ }^{126}$ The types and the minimum size of registrable vessels also differ. With respect to corporate equity participation by foreigners, the Thai registry is the most restrictive. It allows a maximum of 30 percent foreign shareholders in a company engaged in domestic shipping. ${ }^{127}$ This is followed by the Philippines at 40 percent and Malaysia and Indonesia at 49 percent. ${ }^{128}$

A similar divergence is also seen in the licensing requirements. Malaysia issues one license per ship, while the Philippines and Indonesia issue a license to

\footnotetext{
$119 \mathrm{MSO}, \S \S 65 \mathrm{KA}(3) \& 65 \mathrm{~L}$.

120 Indonesian Maritime Law No. 17/2008, art. 284.

1211938 Thai Vessels Act, $\S \S 62$ bis \& 63 ter. (amended by Thai Vessels Act (No. 5) 1991).

122 Revised Implementing Rules 2009, Rule VI, §16.

123 MARINA Circular 2011-04, art. IX.

124 Revised Implementing Rules 2009, Rules VI, §16 \& VII, §(3).

125 Part IV(a) of this article.

126 MARINA Memorandum Circular No. 182 (2003), art. IV(1).

1271938 Thai Vessels Act as amended by the Thai Vessels Act (No. 6) in 1997.

128 The Philippines DSDA 2004, §3(c) \& Malaysia's MSO 1952, §11(1) \& Indonesian Maritime Law No. 17/2008, art. $158(2)(\mathrm{c})$
} 
a qualified shipping entity for the entire fleet. ${ }^{129}$ In the Philippines, some licenseholding companies do not even need to own a vessel, but may merely charter in, register and license the vessel for operation. ${ }^{130}$ Licenses in the Philippines are valid for up to 25 years, except for bareboat chartered ships. ${ }^{131}$ In Malaysia, the maximum period of license validity is 2 years. The mandatory participation of bumiputra employees, shareholders and directors is required as a pre-condition for the issuance of a license. ${ }^{132}$ This is quite unique. The extent of the exemptions that the countries grant to foreign vessels is equally different. Exemptions can be granted for the carriage of goods and passengers between specified routes and ports in Malaysia. ${ }^{133}$ In Indonesia, however, exemptions apply only to offshore oil and gas activities and do not apply to ordinary cargo and passenger transport. ${ }^{134}$

The crewing requirements on flag vessels are not uniform. All Indonesian flagged vessels must be manned by Indonesian crew, ${ }^{135}$ while Malaysia allows up to 25 percent foreign crew on flag vessels. ${ }^{136}$ The Philippines enforces an all-Filipino crew requirement not only on flag vessels, but also on foreign vessels temporarily registered for the duration of a bareboat charter. ${ }^{137}$ These disparities in crewing requirements translate into differences in operating costs under the different ASEAN flags.

The Philippines MARINA is empowered to prescribe routes and areas of operation for flag vessels. In exercising this power, it may require a ship owner to provide transport services to any underserviced areas and can also intervene to adjust the routes and rates charged for the service whenever public interest demands. ${ }^{138}$ This power is not exercised by the authorities of the non-archipelagic ASEAN States.

The introduction of a regional register for the ASEAN ships has been suggested as a way to deal with the disparities. ${ }^{139}$ However, this will not be necessary if the

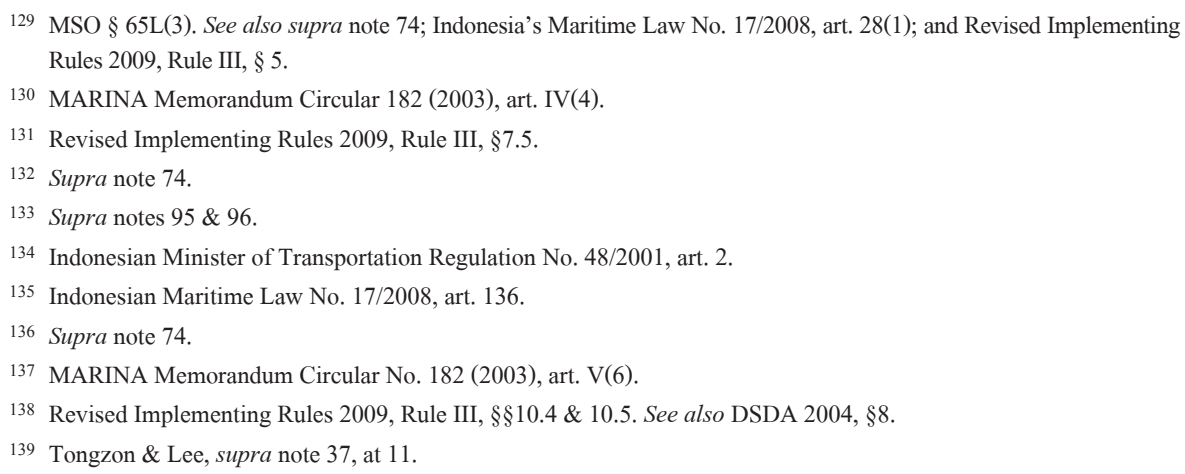


principles and requirements under the cabotage policies can be harmonized through a region-wide regulatory instrument. For this purpose, a new agreement is proposed to delineate the ASEAN's common cabotage policy. It is worth recalling that at the time of adopting the EU Regulation 3577/92, the cabotage policies and regulations of the EU Member States were not uniform, either.

The gaps that existed in the regimes of the EU States were as wide as those of today's ASEAN States in terms of flag registration, vessel licensing, acquisition and ownership rules, crewing requirements for flag vessels and the provision of fiscal incentives by States. ${ }^{140}$ Some States like the UK, the Netherlands and Ireland had the open coast-line policy without cabotage restriction. Germany and the Southern EU States ${ }^{141}$ enforced flexible to strict cabotage policies. ${ }^{142}$ Yet, the EU neither dealt with these differences through a European ship registry, nor rejected the abolition of cabotage restriction for community ship-owners. ${ }^{143}$ Instead, the EU adopted a common cabotage policy and harmonized the rules for freedom to perform maritime transport services under EU Regulation 3577/92.

As regards crewing, the ASEAN States could do more to facilitate free intraASEAN movement of seafarers for work. One way to achieve this would be to expand and accelerate the ASEAN Mutual Recognition Arrangements ("MRAs") 144 program which is already in place for some professional fields. Generally, the ASEAN States have been slow in according full effect to the MRAs. ${ }^{145}$ However, the program and the implementation of the International Convention on STCW by the ASEAN States could improve the ability of seafarers to be employed in other ASEAN countries. ${ }^{146}$ These would more comprehensively deal with the disparity in

140 See The First Report from the European Commission to Council on the Implementation of Council Regulation 3577/92, 06.09.1995 COM (95)383, Annex 1, available at http://eur-lex.europa.eu/legal-content/EN/TXT/PDF/?uri=CELEX:51 995DC0383\&from=EN (last visited Apr. 24, 2017).

141 Namely, France, Italy, Greece, Spain and Portugal.

142 See The Second Report from the European Commission to Council on the Implementation of Council Regulation 3577/92, 17.06.1997 COM (97) 296 Final, at 5, available at http://eur-lex.europa.eu/legal-content/EN/TXT/PDF/?uri= CELEX:51997DC0296\&qid=1493048554286\&from=EN (last visited Apr. 24, 2017).

$143 \mathrm{See}$ The Communication from the Commission of the European Communities, Towards a New Maritime Strategy 13.03.1996 COM (96) 81 Final, at 9 \& 16, available at http://eur-lex.europa.eu/legal-content/EN/TXT/PDF/?uri=CEL EX:51996DC0081\&qid=1493049982177\&from=EN (last visited Apr. 24, 2017).

144 The Mutual Recognition Arrangements ("MRAs") facilitates trade in services by the recognition of professionals who are authorized, licensed or certified by the respective authorities of the ASEAN Member States within the framework of MRAs. See Building the ASEAN Community: Mutual Recognition Arrangements in Services, available at http:/ www.asean.org/storage/images/2015/October/outreach-document/Edited\%20MRA\%20Services-2.pdf (last visited on Mar. 25, 2017).

145 Supra note $9, \uparrow 63$.

146 The EU dealt with the free movement of skilled labor within the Union. See Treaty Establishing the European Community, 2002 O.J.C. 325/33, arts. 3(c) \& 48(3). 
crewing requirements for vessels flying the flag of the ASEAN States. A region-wide solution is certainly preferable to the bilateral agreement approach currently adopted by some ASEAN States. ${ }^{147}$

Lastly, as to the geographical reach for cabotage restriction, it is necessary to identify a uniform scope for its enforcement in the ASEAN territory. Thailand's contiguous zone limit is twice as wide as the breadth of the territorial waters limit in which Indonesia enforces cabotage. ${ }^{148}$ However, this is just a fraction of the 200 nautical miles EEZ in which the Philippine and Malaysian authorities exercise cabotage jurisdiction to the exclusion of foreigners. In harmonizing the principle under the proposed ASEAN agreement, the EU position could be adopted. The provision under EU Regulation 3577/92 allows the community ship-owners to provide maritime services up to the continental shelf of any EU country. ${ }^{149}$ That limit is wide enough to protect the interests of the offshore oil producing ASEAN States which need to enforce cabotage restriction beyond the territorial waters.

\section{Towards an ASEAN Cabotage Region: Challenges and Prospects}

In order to harness the disparate ASEAN cabotage regimes under a common policy and move towards a single shipping market, a new ASEAN agreement is essential for liberalizing domestic shipping in the region. In this process, the ASEAN could learn from the EU which faced similar challenges in its early years. Like the ASEAN, the EU Member States differed in geographical features (consisting of island, coastal and landlocked states). ${ }^{150}$ They were not homogeneous in terms of economic development, domestic shipping policies and the capacity of merchant fleets either. ${ }^{151}$ EU Regulation 3577/92 was indeed a delicate political and economic balance catering

147 Malaysia has signed the STCW 95 Regulation 1/10 undertaking to recognize the certificates of seafarers from the Philippines, Vietnam, Singapore, Brunei and Thailand. See the official website of the Marine Department of Malaysia, available at http://www.marine.gov.my/jlmeng/Content_public.asp?article_id=794\&category_id=1\&subcategory_ id=24\&subcategory2_id=0\#.WNaWDm997IV (last visited on 25 March, 2017). Singapore has similar MoU with some ASEAN States. These aim at dealing with the shortage of qualified vessel crew in Malaysia and Singapore.

148 Part IV(F) of this paper.

149 EU Regulation 3577/92, art. 2(1).

150 The EU landlocked states, namely, Luxemburg, Austria, Hungary, Czech Republic and Slovakia participate in the cabotage freedom granted to European Community Ship-owners under the EU Regulation 3577/92.

151 Supra note 142 , at 23. 
to the different interests of the Northern and Southern States. ${ }^{152}$ An interesting point (which should allay the fears of the ASEAN cabotage skeptics) is that even after 20 years of the liberalization of cabotage in the EU no significant negative alteration in the domestic shipping trade pattern of the most EU Members has been observed. ${ }^{153}$ Accordingly, the ASEAN should consider adopting the considerations below, some of which have been applied in achieving the European cabotage liberalization.

\section{A. A Flexible and Tailored Approach to Liberalization}

The AEC Blueprint 2015 and the following Roadmap and Strategic Action Plan recognize 'flexibility' as key to realizing the goals of an internal market. As the ASEAN is diverse and its Member States are at different stages of economic development, there is a need for tailored approaches to policy and strategy. A flexible approach should be adopted in liberalizing cabotage in the ASEAN. The AEC Blueprint 2015 endorses flexibility under the "ASEAN minus X formula." This allows any ASEAN countries ready to liberalize trade in goods or services in any given sector to proceed and be joined later by others. ${ }^{155}$ Notably, the EU took a similar approach under EU Regulation 3577/92. The preamble to that Regulation stated:

The implementation of the freedom should be gradual and not necessarily in a uniform way for all services concerned, taking into account the nature of certain specific services and the extent of the effort that certain economies in the Community showing differences in development will have to sustain.

Due to the above approach, Southern EU States which were concerned about the economic impact of opening up their cabotage trade at the same time as others were allowed to delay the implementation of the Regulation. ${ }^{156}$ The exemptions granted

152 Supra note 140 , at 2.

153 See The Fifth Report from the European Commission to the Council on the Implementation of Council Regulation 3577/92, 22.04.2014 COM (2014) 231 Final, at 10, available at http://eur-lex.europa.eu/legal-content/EN/TXT/PDF/?u ri=CELEX:52014DC0231\&from=EN (last visited Apr. 24, 2017).

154 AEC Blueprint 2015, ๆ 21(ix).

155 The formula was adopted successfully under the 1992 Free Trade Area Agreement.

156 EU Regulation 3577/92, art. 6(1). It exempted maritime transport services carried out in the Mediterranean and along the coast of Spain, Portugal and France until the following periods: cruise services (Jan., 1995), transport of strategic goods (Jan. 1, 1997), services by smaller vessels (Jan. 1, 1998), regular passenger and ferry services (Jan. 1, 1999). In addition, island cabotage along the Mediterranean and other Southern European islands and archipelagoes were exempted until January 1, 1999. 
to them were rationalized on "grounds of socio-economic cohesion." 157 One of the exemptions continued to apply for 10 years after the Regulation was in force in other States. ${ }^{158}$

Some of the poorer ASEAN States have reasonable concerns about protecting their sensitive routes and services from foreign competition. ${ }^{159}$ They could be granted exemptions under the proposed ASEAN agreement so that they do not lose out from opening them up at the same time as others. Also, more established market economies in the ASEAN (the so-called ASEAN 6) ${ }^{160}$ could proceed by adopting the proposed agreement first, with the less developed Members acceding to it later.

\section{B. The 'Golden Rule ${ }^{9161}$ Model of Liberalization}

The liberalization of cabotage in the EU was based on the mutual recognition of freedom by ship-owners to provide maritime transport services anywhere within the European community. ${ }^{162}$ This right to participate in another country's domestic trade was granted to ships that had fulfilled the conditions for engaging in domestic shipping in their own flag state. ${ }^{163}$

This EU model should be adopted under the proposed ASEAN agreement. Ships registered in one ASEAN Member State (the flag state) and who can provide cabotage services there should be allowed to do so in other Member States (the host states). Each country will still have to determine whether a ship can fly its flag by setting the conditions for registering ships in its jurisdiction. For security and economic reasons, both the host and flag states are interested in controlling issues such as the crewing of vessels. ${ }^{164}$ These issues can be comprehensively and uniformly dealt with under the proposed ASEAN agreement.

\footnotetext{
157 EU Regulation 3577/92, art. 6(3).

158 The derogation in favor of Greece lasted until January 1, 2004. See id.

159 G. Llanto \& A. Navarro, Toward Relaxing the Cabotage Restrictions in Maritime Transport, PhiLIPPINE Inst. Dev. Stud. Pol'y Notes (2014-03), available at http://dirp3.pids.gov.ph/webportal/CDN/PUBLICATIONS/pidspn1403.pdf (last visited on Mar. 25, 2017).

160 Malaysia, Indonesia, Singapore, Thailand, Philippines and Brunei.

161 The 'golden rule' is defined as "the ethical principle that one should behave toward others as one would have others behave toward onself." See The Free Dictionary by Farlex, available at http://www.thefreedictionary.com/golden+rule (last visited on Mar. 25, 2017).

162 EU Regulation 3577/92, pmbl.

163 Petrova, supra note 19, at 1074. In cabotage trade in the EU, he maintained: "If a vessel is capable of carrying out adequate cabotage services in the flag state, it is deemed fit for that purpose in any member state."

164 EU Regulation 3577/92, art. 3. See also P. Bryng \& M. Jonassen, Maritime Cabotage: New Guidelines from the European COMmission (2014), available at http://svw.no/contentassets/0a5911c92d7447df91c2870f9a313713/ maritime-cabotage---new-guidelines-from-the-european-commission.pdf (last visited on Mar. 25, 2017).
} 


\section{Delineate the Geographical Reach}

Under the proposed ASEAN agreement, it is important to define the geographical scope of the activities where the freedom will apply to all States. The EU Regulation 3577/92 specifies mainland cabotage, offshore supply services and island cabotage as the maritime transport services to which the cabotage freedom applies. ${ }^{165}$ In order to cater for the offshore activities which sometimes take place beyond the EEZ of the EU coastal States, the freedom to provide cabotage services is extended as far as the continental shelf ${ }^{166}$ of each country. ${ }^{167}$ In view of the EU position, it is advisable for the ASEAN to adopt a uniform geographical delimitation for the enforcement of cabotage. It must jettison the inconsistent rules (such as the territorial water, contiguous zone and exclusive economic zone) that apply under each Member's law.

\section{Defining an ASEAN Regional Ship owner}

The ASEAN Member States have different criteria for the qualification to be a domestic ship owner and the eligibility to register and license a vessel for operation. ${ }^{168}$ A clearly defined concept of a regional ship owner in the proposed ASEAN agreement will be beneficial, as this will identify who the beneficiaries of the cabotage freedom are. The proposed agreement could define a regional ship owner as:

(a) a national of an ASEAN Member State established in and pursuing shipping activities in the ASEAN, or

(b) a company established in accordance with the laws of a Member State and carrying on business there and in which up to $70 \%$ of the shares are held by ASEAN Member State nationals.

This definition will meet the requirement of the AEC Blueprint 2015 that Member States should allow corporate equity participation by the ASEAN Members of not

165 EU Regulation 3577/92, art. 2(1).

166 UNCLOS art. 76(1). It defines 'continental shelf' of a coastal state as comprising "the sea bed and subsoil of the submarine areas that extend beyond its territorial sea throughout the national prolongation of its land territory to the outer edge of the continental margins or to a distance of 200 nautical miles from the baseline from which the breadth of the territorial sea is measured."

167 EU Regulation 3577/92, art. 2(1)(b). It states that offshore activities includes the carriage of passengers or goods by sea between any ports in a member state and installations and structures situated on the continental shelf of that member state.

168 Part IV(A) of this paper. 
less than 70 percent by $2015 .{ }^{169}$ It will also enable non-ASEAN investors to acquire up to 30 percent equity in domestic shipping companies. This will help the ASEAN to attract the much needed foreign direct investment in the shipping sector. The proposed ASEAN agreement could stipulate that only companies effectively controlled by the ASEAN nationals and whose principal place of business is located in the ASEAN qualify as regional ship-owners. ${ }^{170}$ Shipping companies established in non-ASEAN States could also qualify as regional ship-owners if they are controlled by the ASEAN nationals and their ships are flagged in the ASEAN. This would ensure that the ASEAN citizens and companies indeed benefit from the liberalization of cabotage. Also, any regional fiscal incentives for the promotion of the shipping industry should benefit only ASEAN ship-owners.

\section{E. Public Service Contracts and Obligations}

The ASEAN States like the Philippines ${ }^{171}$ and Indonesia ${ }^{172}$ control the routes, services, freight rates and fees offered by domestic ship-owners. The maritime authorities intervene in the operation of ship-owners to protect consumers whenever necessary to ensure that the rates and standards of services are satisfactory. This practice enables these archipelagic States to ensure the availability and reasonableness of services to their islands and remote regions. It would be impossible if the provision of those services were simply left to market forces. The proposed ASEAN cabotage agreement should address such a problem. It should permit the ASEAN States to impose public service contracts ${ }^{173}$ and public service obligations ${ }^{174}$ on other ASEAN ship-owners trading or engaged in their important domestic routes. ${ }^{175}$ The parameters of the contracts and obligations should be clearly set out in the proposed agreement. E.g., the EU considers 12 years to be reasonable as the length of a public

\footnotetext{
169 AEC Blueprint 2015, art. 21(V). See also supra note 14.

170 Malaysia, e.g., already required the establishment of the principal place for business and management of the shipping company in its territory as conditions for participating in domestic shipping. See Malaysian Merchant Shipping Ordinance 1952, $\$ 11(1)(\mathrm{b})$.

171 Revised Implementing Rules 2009, Rule III, $\S \S 8.1,8.2$ \& 8.4.

172 Indonesian Maritime Law No. 17/2008, arts. 35-39.

173 EU Regulation 3577/92, art. 2(3). It defines a public service contract as "a contract between a member state and community shipowner in order to provide the public adequate transport services."

174 Id. art. 2(4). It defines a public service obligation as "an obligation which the community shipowner in question, if he were considering his own commercial interest would not assume or would not assume to the same extent or under the same condition."

175 Id. art. 4.
} 
service contract or obligation. ${ }^{176}$

\section{F. Safeguard Measures}

In a situation where the proposed agreement on cabotage causes serious disturbance to an ASEAN State's economy, such a State should be allowed temporary exemption from the agreement. A special ASEAN institution should be established to monitor the effects of the proposed agreement on Member States. Any requesting ASEAN States should be permitted to adopt safeguard measures and obtain relief against undue hardship resulting from the agreement. The proposed ASEAN agreement should clearly define the safeguard measures that may be adopted and the procedures for applying them. ${ }^{177}$

\section{G. The ASEAN Cabotage Commission}

Under the proposed ASEAN agreement, an ASEAN cabotage commission should be established and given responsibility for monitoring the impact of the cabotage liberalization in the region. It should function as an anti-competition watchdog and work in line with the ASEAN competition policy for the maritime sector. ${ }^{178}$ The proposed institution should take action when necessary to adjust any reported harmful competition caused by the creation of a single ASEAN market in maritime transport. The institution should also be empowered to receive, evaluate and decide reported cases involving serious disturbance in the economy of Member States. As there is not yet a supranational judicial institution in the ASEAN, ${ }^{179}$ Member States will rely on the new institution for the interpretation of the proposed agreement. It seems clear that the EU cabotage liberalization would not have succeeded without the institutional role played by the EU Commission. ${ }^{180}$

176 Supra note 153 , at 55.

177 EU Regulation 3577/92, art. 5.

178 See The ASEAN Regional Guidelines on Competition Policy (2010), available at http://asean.org/?static_post=aseanregional-guidelines-on-competition-policy-3 (last visited on Mar. 25, 2017).

179 T. Schmitz, The ASEAN Economic Community and the Rule of Law, Dec. 15, 2014, available at http://home. lu.lv/ tschmit1/Downloads/BDHK-Workshop_15-12-2014_Schmitz.pdf (last visited on Mar. 25, 2017).

180 EU Regulation 3577/92, arts. 5, 9 \& 10. These articles stipulate the safeguard measures against hardship, advising on the adoption of new cabotage laws in member states and furnishing the EU Council with reports and proposals on the implementation of the Regulation. 


\section{Conclusion}

If the ASEAN truly wishes to carry through the measures necessary to achieve its goal of establishing a single shipping market, it cannot in the long run help but liberalize domestic and coastal trade. This would permit the ASEAN ship-owners to engage in the domestic shipping within each other's territory. This is the only way to bring about the kind of economic growth in the maritime sector which the ASEAN aspires to achieve through regionalization. The EU was able to achieve a single market in maritime transport after including cabotage within the liberalized common market. Such a move in the ASEAN would also foster connectivity and competitiveness in maritime transport which are vital to the ASEAN's sustained economic growth and resilience. ${ }^{181}$ Following the liberalization of cabotage, the ASEAN could be truly integrated into the global economy as a formidable central power in the whole East Asian region.

The concerns currently holding the ASEAN States back in opening up domestic shipping are similar to those that troubled the EU in its early days of economic integration. Going by the EU's positive cabotage experience, the ASEAN is likely to be economically stronger in domestic shipping if it follows the EU pattern. To achieve this, the ASEAN needs a maritime cabotage agreement that will not only harmonize currently diverse principles into a common cabotage policy, but also place all Member States on the same level playing field. Some issues still remain to be worked out under the proposed agreement. These are: defining the beneficiaries of the cabotage freedom, the geographical scope of the freedom, the areas deserving of exemptions or derogation and the way to deal with serious and harmful distortions of competition if and when they occur. Above all, the ASEAN should entrust the task of supervising compliance, dealing with complaints and recommending improvements to the agreement to a new commission on the ASEAN cabotage.

181 Pushpanathan, supra note 39. 